\title{
Plasmid analysis of Mycobacterium avium-intracellulare (MAI) isolated in the United Kingdom from patients with and without AIDS
}

\author{
T. J. HELLYER, I. N. BROWN*, J.W. DALE† and C. S. F. EASMON
}

Department of Medical Microbiology, St Mary's Hospital Medical School, London W2 1PG and tDepartment of Microbiology, University of Surrey, Guildford, Surrey GU2 5XH

\begin{abstract}
Summary. One hundred and forty-seven isolates (128 strains) of Mycobacterium aviumintracellulare (MAI) were screened by agarose gel electrophoresis for the presence of plasmids. Plasmids were characterised according to size and by Southern hybridisation analysis of intact and restriction endonuclease-digested DNA. Two cloned MAI plasmids, pLR7 and pLR20, were used as probes. There was no significant difference in the rate of plasmid carriage in MAI strains isolated from patients with the acquired immuno-deficiency syndrome (AIDS) and from non-AIDS patients in the UK, but a higher rate of plasmid carriage was observed in a panel of American strains from AIDS patients. Plasmids were grouped into two broad categories: small (mostly $14-30 \mathrm{~kb}$ ) and large ( $>150 \mathrm{~kb}$ ). Southern blot analysis identified two distinct groups of small plasmids, the majority of which showed homology with pLR7. Plasmids from this group were significantly more common in strains of serotypes 4 and 8 which are particularly associated with AIDS.
\end{abstract}

\section{Introduction}

Organisms of the Mycobacterium avium-intracellulare (MAI) complex are the most common cause of systemic bacterial infection in patients with the acquired immunodeficiency syndrome (AIDS). Over $50 \%$ of AIDS patients may be infected with MAI at some stage of their disease. ${ }^{1-3}$

The reasons for the close association between MAI and AIDS are not known. The pattern of disease suggests that infection occurs via the gastrointestinal tract rather than by the respiratory route. ${ }^{1-4}$ Infection is frequently associated with abdominal pain, diarrhoea and malabsorption. Large numbers of MAI organisms may be found in faeces and in biopsy tissue from the gastrointestinal tract, and the recovery of MAI from these specimens has been correlated with invasive disease. ${ }^{2-6}$

The MAI complex comprises two biochemically closely-related species, M. avium and $M$. intracellulare, which may be distinguished by serological and genetic analyses. Good ${ }^{7}$ reported that over $60 \%$ of MAI isolates from patients with AIDS were either serotype 4 or 8 . Both these serotypes are identified as $M$. avium by DNA homology studies. ${ }^{8,9}$ Guthertz et al. ${ }^{10}$ used species-specific probes to analyse MAI isolates from patients with and without AIDS; $98 \%$ of strains from AIDS patients were $M$. avium compared with only $60 \%$ of strains from patients without AIDS. All the remaining strains were $M$. intracellulare. Therefore, it

Received 14 May 1990; accepted 5 Sep. 1990.

- Correspondence should be sent to Dr I. N. Brown. appears that not all members of the MAI complex are equally capable of causing infection in patients with AIDS.

In 1986, Crawford and Bates ${ }^{11}$ reported that all of 26 MAI isolates from patients with AIDS possessed plasmid DNA, and suggested that plasmids might have an important role in the pathogenesis of MAI infection in AIDS. Recent studies have associated plasmid carriage with virulence as determined by measurements of catalase activity, ${ }^{12}$ mortality rates in beige mice and the release of oxygen metabolites by murine macrophages. ${ }^{13,14}$

We report a survey of plasmid carriage in MAI strains isolated in the UK from patients with and without AIDS. Plasmids were characterised according to size, by analysis of restriction digest patterns, and by Southern hybridisation with two cloned MAI plasmids as probes.

\section{Materials and methods}

\section{Mycobacterial strains}

MAI strains from patients with AIDS were either isolated at St Mary's Hospital or kindly provided by Dr P. A. Jenkins, Mycobacterium Reference Unit, Public Health Laboratory, Cardiff, Mrs M. Chadwick, The Brompton Hospital, London, and Mr M. Yates, Regional Centre for Tuberculosis, Dulwich, London, who also provided a panel of strains from patients who did not have AIDS. AIDS-related MAI isolates from the USA were obtained from Mr R. A. Ollar, St 
Vincent's Hospital, New York, USA. Veterinary strains were donated by Dr E. Boughton, Central Veterinary Laboratory, Weybridge, and by the Regional Centre for Tuberculosis, Dulwich. MAI strains LR25 and LR113, which were used as standards in plasmid characterisation, were provided by $\mathrm{Dr} \mathrm{J}$. T. Crawford, The John L. McClellan Veterans' Hospital, Little Rock, AS, USA.

Serotyping of AIDS-related MAI isolates was performed at the Centers for Disease Control, Atlanta, GA, USA according to standard methods. ${ }^{15}$ Serological analysis was not available for strains isolated from patients without AIDS.

\section{Plasmid screening}

Screening of MAI for plasmid carriage was performed by a procedure modified from those of Crawford et al. ${ }^{16}$ and Kieser. ${ }^{17}$ Mycobacteria were grown for $14-16$ days at $37^{\circ} \mathrm{C}$ in $10 \mathrm{ml}$ of Middlebrook 7H9 Broth (Difco) containing oleic acid/albumin/ dextrose/catalase (OADC) $10 \% \mathrm{v} / \mathrm{v}$ and glycerol $0 \cdot 2 \%$ $\mathrm{v} / \mathrm{v}$. Cycloserine and ampicillin (Sigma) were added to final concentrations of $1.0 \mathrm{mg} / \mathrm{ml}$ and $0.1 \mathrm{mg} / \mathrm{ml}$ respectively. Bacteria were incubated for a further 20 $22 \mathrm{~h}$ at $37^{\circ} \mathrm{C}$, harvested by centrifugation $(1000 \mathrm{~g}$, $10 \mathrm{~min}$ ) and resuspended in $500 \mu \mathrm{l}$ of a freshly prepared solution containing lysozyme (Sigma) $2 \mathrm{mg} / \mathrm{ml}, 0 \cdot 3 \mathrm{M}$ sucrose, $25 \mathrm{~mm}$ Tris-HCl (pH 8.0) and $25 \mathrm{~mm}$ EDTA (pH 8.0). Suspensions were incubated for $3-24 \mathrm{~h}$ at $37^{\circ} \mathrm{C}$. Cells were lysed by adding $250 \mu \mathrm{l}$ of alkaline sodium dodecyl sulphate (SDS) $2 \% \mathrm{w} / \mathrm{v}$ in $0.3 \mathrm{M} \mathrm{NaOH}$ and incubation at $70^{\circ} \mathrm{C}$ for $20 \mathrm{~min}$. Lysates were cooled, and extracted twice with $750 \mu \mathrm{l}$ of phenol:chloroform (phenol $5 \mathrm{~g}$ : chloroform $5 \mathrm{ml}$ ). A 50- $\mu$ l sample of clear aqueous phase was mixed with $10 \mu \mathrm{l}$ of loading buffer (sucrose $60 \% \mathrm{w} / \mathrm{v} ; 100 \mathrm{mM}$ EDTA; bromophenol blue $0.25 \% \mathrm{w} / \mathrm{v}$ ) and loaded on to a horizontal agarose $0.5 \% \mathrm{w} / \mathrm{v}$ gel for electrophoresis at $1.8 \mathrm{~V} / \mathrm{cm}$ for $16 \mathrm{~h}$ in TAE buffer $(40 \mathrm{mM}$ Tris acetate, $\mathrm{pH} 7 \cdot 9,2 \mathrm{mM}$ EDTA). Gels were stained for $30 \mathrm{~min}$ in ethidium bromide $0.5 \mu \mathrm{g} / \mathrm{ml}$ solution, destained for $1-2 h$ in distilled water, examined under ultra-violet illumination $(302 \mathrm{~nm})$ and photographed.

Plasmids were classified as small or large by virtue of their migration in agarose gels relative to two small plasmids of $18 \mathrm{~kb}$ and $28 \mathrm{~kb}$ and one large plasmid (> $150 \mathrm{~kb}$ ) isolated from strain LR25. ${ }^{18}$

DNA was transferred over 20-24 h to nylon hybridisation membranes (Dupont GeneScreen Plus) by Southern blotting in alkaline conditions, with $0.4 \mathrm{M}$ $\mathrm{NaOH}, 0.6 \mathrm{M} \mathrm{NaCl}$ as the transfer buffer. Membranes were neutralised by soaking for $15 \mathrm{~min}$ in $0.5 \mathrm{M}$ Tris$\mathrm{HCl}(\mathrm{pH} 7 \cdot 0), 1 \mathrm{M} \mathrm{NaCl}$, dried and stored desiccated.

\section{Probes}

Two MAI plasmids, pLR7 and pLR20, that had been cloned into Escherichia coli were used as probes. No homology exists between these two plasmids. The recombinant $\mathrm{pLR} 7:: \mathrm{pBR} 322$ plasmid (pJC20) has been described elsewhere ${ }^{19}$ and was provided by $\mathrm{Dr}$ J. T. Crawford, The John L. McClellan Memorial Veterans' Hospital, Little Rock, AS, USA.

The second probe ( $\mathrm{pJC} 70$ ) was derived from the plasmid pLR20 which was extracted from a serotype 4 MAI strain, isolated from an AIDS patient in the USA. The pLR20 plasmid was isolated and cloned (by T.J.H.) in collaboration with Dr Crawford at the Veterans' Hospital. Briefly, plasmid DNA was extracted from MAI strain LR541 (which was obtained by Dr Crawford from the Centers for Disease Control, Atlanta, GA, USA) as described above and further purified by the Geneclean procedure (Bio 101 Inc., La Jolla, CA, USA). DNA was digested with the restriction endonuclease $E c o$ RI and ligated into the polycloning site of the $E$. coli vector $\mathrm{pUC} 18^{20}$ by standard methods. DNA from the ligation mixture was used to transform E. coli strain DH5a ( $\left.\mathrm{amp}^{\mathrm{s}} \mathrm{lac}^{-}\right)$. Transformation and insertion of DNA were monitored by culture on medium containing ampicillin and the chromogenic substrate 5-bromo-4-chloro-3-indolyl- $\beta$ D-galactoside (X-gal). Bacteria carrying recombinant plasmids were unable to utilise the chromogenic substrate and formed white colonies. Minipreparations of plasmid DNA were performed and clones were characterised by analysis of restriction fragments and Southern hybridisation.

Probes were labelled with ${ }^{32} \mathrm{P}$-deoxycytidine triphosphate by random hexanucleotide priming of DNA polymerase ${ }^{21,22}$ by the Amersham Multiprime system (Amersham International, Little Chalfont, Berks).

\section{Hybridisation}

Prehybridisation, hybridisation and washing of membranes were all performed at $60^{\circ} \mathrm{C}$. Membranes were prehybridised for $3-4 \mathrm{~h}$ in a mixture containing 6X SSC, 5X Denhardt's solution and SDS $0.5 \% \mathrm{w} / \mathrm{v}$; $20 \mathrm{X} \mathrm{SSC}$ is $3 \mathrm{M} \mathrm{NaCl}, 0.3 \mathrm{M}$ sodium citrate; $10 \mathrm{X}$ Denhardt's solution is polyvinyl pyrrolidone $\left(M_{r} 40000\right) 0.02 \%$ w/v, ficol $\left(M_{r} 400000\right) 0.02 \%$ w/v and bovine serum albumin (fraction V) $0.02 \% \mathrm{w} / \mathrm{v}$ in water. Hybridisation was performed overnight in a mixture which differed from the prehybridisation fluid in that it also contained 0.01 M EDTA. Membranes were washed for $2 \mathrm{~h}$ in $0.1 \mathrm{X} \mathrm{SSC}$, SDS $0.1 \% \mathrm{w} / \mathrm{v}$, with a change of washing solution every $30 \mathrm{~min}$. Autoradiographs were exposed at $-70^{\circ} \mathrm{C}$ to Amersham Hyperfilm with Rapid-X intensifying screens (Genetic Research Instrumentation, Dunmow, Essex).

\section{Restriction digestion}

DNA for restriction analysis was purified by anion exchange chromatography by the Qiagen DNA purification system (Diagen GmbH, Dusseldorf, Germany). Cells were grown with shaking at $37^{\circ} \mathrm{C}$ in $200 \mathrm{ml}$ of Middlebrook 7H9 broth (containing OADC 
$10 \% \mathrm{v} / \mathrm{v}$ and glycerol $0 \cdot 2 \% \mathrm{v} / \mathrm{v}$ ) to mid-exponential phase. Cycloserine and ampicillin were added as previously described and incubation was continued for 20-22 h. Bacteria were harvested by centrifugation and resuspended in $4 \mathrm{ml}$ of RNAase buffer $(50 \mathrm{mM}$ Tris-HCl, 10 mm EDTA, RNAase A, Sigma, $400 \mu \mathrm{g} /$ $\mathrm{ml})$. Cells were lysed at room temperature by addition of $4 \mathrm{ml}$ of alkaline SDS (SDS $1 \% \mathrm{w} / \mathrm{v} ; 0.2 \mathrm{M} \mathrm{NaOH}$ ). Cell debris and SDS were precipitated by addition of $4 \mathrm{ml}$ of potassium acetate $(2.55 \mathrm{M}, \mathrm{pH} 4.8)$ and incubation on ice for $10 \mathrm{~min}$. Lysates were centrifuged at $20000 \mathrm{~g}$ for $30 \mathrm{~min}$ at $4^{\circ} \mathrm{C}$ and the clear supernate was loaded onto a Qiagen Tip-20 chromatography column that had been pre-equilibrated with buffer $\mathrm{A}-1 \mathrm{M}$ $\mathrm{NaCl}, 50 \mathrm{~mm}$ morpholinopropanesulphonic acid (MOPS), ethanol 15\% v/v, pH 7.0. DNA was allowed to bind to the chromatography resin by slow passage of the lysate through the column. The resin was washed with $6 \mathrm{ml}$ of buffer $\mathrm{B}(1.2 \mathrm{M} \mathrm{NaCl}, 50 \mathrm{mM}$ MOPS, ethanol $15 \% \mathrm{v} / \mathrm{v}, \mathrm{pH} 7 \cdot 0)$ to remove impurities, and the DNA was eluted with $2 \mathrm{ml}$ of buffer $\mathrm{C}(1.2 \mathrm{M}$ $\mathrm{NaCl}, 50 \mathrm{~mm}$ MOPS, ethanol $15 \% \mathrm{v} / \mathrm{v}, \mathrm{pH} \mathrm{8.0)}$. DNA was precipitated with 0.8 volumes of isopropanol at room temperature, washed in ethanol $70 \% \mathrm{v} / \mathrm{v}$ and resuspended in $100 \mu \mathrm{l}$ of TE buffer ( $10 \mathrm{mM}$ Tris- $\mathrm{HCl}$, 1 mM EDTA, pH 8.0).

Plasmids were compared by digestion with the restriction endonuclease BstEII (Gibco BRL) for $2 \mathrm{~h}$ at $60^{\circ} \mathrm{C}$ in buffer containing $50 \mathrm{~mm}$ Tris- $\mathrm{HCl}, \mathrm{pH} 8.0$, $10 \mathrm{mM} \mathrm{MgCl}_{2}, 50 \mathrm{mM} \mathrm{NaCl}$. DNA fragments were separated by electrophoresis through agarose $1 \% \mathrm{w} / \mathrm{v}$ gels at $3.6 \mathrm{~V} / \mathrm{cm}$ for $4-5 \mathrm{~h}$ in TAE buffer. Gels were stained for $30 \mathrm{~min}$ in ethidium bromide $0.5 \mu \mathrm{g} / \mathrm{ml}$ solution, destained for $1 \mathrm{~h}$ in distilled water, examined under UV illumination and photographed. Analysis of restriction digests was complicated by the presence of more than one plasmid in many strains. DNA fragments were transferred to GeneScreen Plus hybridisation membranes as described above, and Southern hybridisation was performed with the two probes to identify fragments with homology to either pLR7 or pLR20.

\section{Statistical analysis}

Rates of plasmid carriage were compared by the $\chi^{2}$ test.

\section{Results}

A total of 147 MAI isolates was examined for plasmid carriage. For the purpose of this study, isolates from the same patient which could not be distinguished by plasmid analysis were considered to represent the same strain. Eighty-eight isolates (71 strains) originated from 70 patients in the UK who had AIDS, nine isolates (nine strains) were from AIDS patients in New York, 36 isolates (34 strains) were from 34 nonAIDS patients in the UK, and 14 isolates (14 strains) were from animals in the UK.

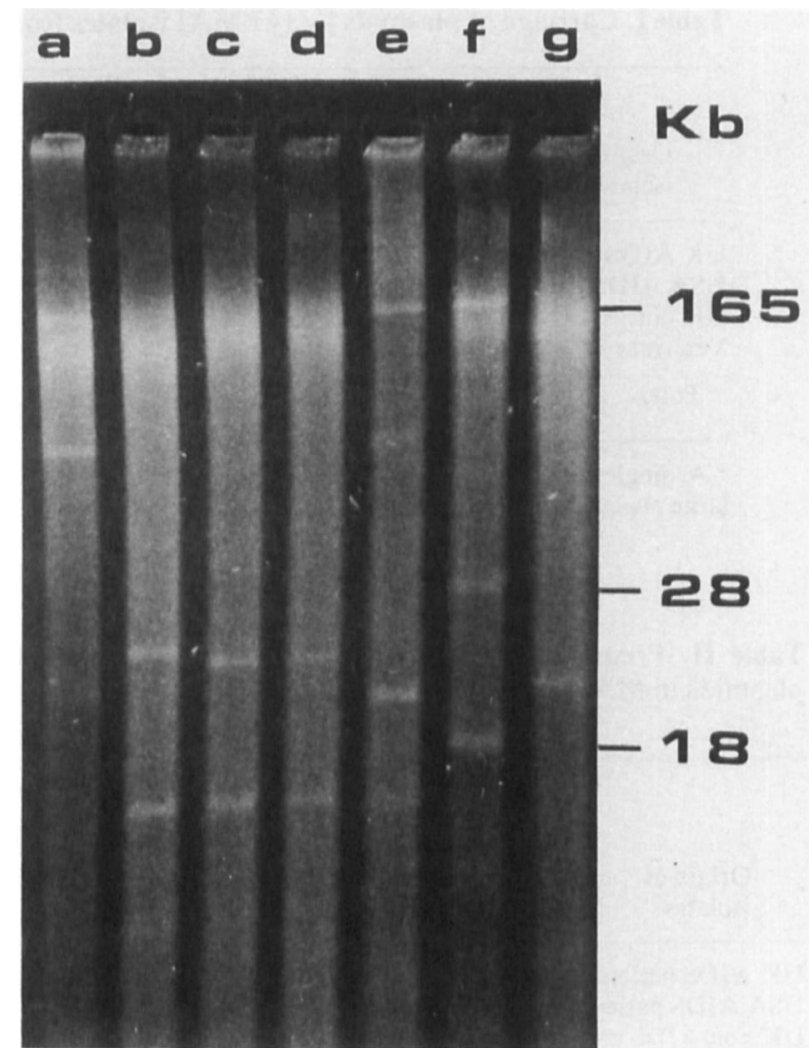

Fig. 1. Agarose gel electrophoresis of crude plasmid DNA. Migration was from top to bottom. $\mathbf{M}_{\mathrm{r}}$ indicated are those of plasmids isolated from strain LR25, ${ }^{18}$ lane $\mathbf{f}$. Strain sources: $\mathbf{a}$, b, UK non-AIDS patients; $c$, d, UK AIDS patient; $e$, US AIDS patients; $g$, veterinary. MAI isolates shown in lanes $c$ and $\mathbf{d}$ were isolated from the blood and faeces of the same patient, and have indistinguishable plasmid banding patterns.

The electrophoretic screening procedure enabled the number and size of plasmids carried by each strain to be determined; a representative screening gel is shown in fig. 1. Plasmids were grouped into two broad size categories: small plasmids, the majority between 14 and $30 \mathrm{~kb}$, and large plasmids which were over $150 \mathrm{~kb}$. The results obtained by screening MAI isolates in this manner are summarised in table I. There was no significant difference in the rate of plasmid carriage between MAI strains isolated in the UK from patients with and without AIDS. However, all the AIDSassociated strains from New York possessed at least one plasmid. Large and small plasmids were found in strains from both AIDS and non-AIDS patients. No large plasmids were isolated from the veterinary strains, although two strains did carry a small plasmid. No MAI strain was found to possess more than three plasmids.

Plasmids were further characterised by Southern hybridisation with two cloned MAI plasmids, pLR7 and pLR20, as probes. Most small plasmids from both AIDS- and non-AIDS-related MAI strains showed homology to pLR7 (table II), as did one of the small plasmids isolated from a veterinary strain. Hybridisation of small plasmids with the pLR20 probe was less 
Table I. Carriage of plasmids by $147 \mathrm{MAI}$ isolates from different sources

\begin{tabular}{|c|c|c|c|c|c|c|c|c|}
\hline \multirow{2}{*}{$\begin{array}{l}\text { Origin of } \\
\text { isolates }\end{array}$} & \multirow{2}{*}{$\begin{array}{c}\text { Number of } \\
\text { isolates }\end{array}$} & \multirow{2}{*}{$\begin{array}{l}\text { Number of } \\
\text { strains }\end{array}$} & \multirow{2}{*}{$\begin{array}{l}\text { Number }(\%) \text { of plas- } \\
\text { mid-carrying strains }\end{array}$} & \multicolumn{5}{|c|}{ Frequency of plasmid-carrying patterns* } \\
\hline & & & & $\mathbf{A}$ & $\mathbf{B}$ & $\mathrm{C}$ & $\mathbf{D}$ & $\mathbf{E}$ \\
\hline UK AIDS patients & 88 & 71 & $34(48)$ & 13 & 4 & 5 & 4 & 8 \\
\hline USA AIDS patients & 9 & 9 & $9(100)$ & 1 & 0 & 3 & 4 & 1 \\
\hline UK non-AIDS patients & 36 & 34 & $12(35)$ & 6 & 0 & 2 & 2 & 2 \\
\hline Veterinary & 14 & 14 & $2(14)$ & 2 & 0 & 0 & 0 & 0 \\
\hline Total & 147 & 128 & $57(45)$ & 22 & 4 & 10 & 10 & 11 \\
\hline
\end{tabular}

* A, single small (14-30 kb) plasmid; B, two small plasmids; C, one small +one large (>150 kb) plasmid; D, two small +one large plasmid; E, single large plasmid.

Table II. Frequency and hybridisation patterns of small plasmids in MAI strains from different sources

\begin{tabular}{lcrr}
\hline & & \multicolumn{1}{c}{$\begin{array}{c}\text { Number (\%) } \\
\text { humbridising with }\end{array}$} \\
$\begin{array}{l}\text { Origin of } \\
\text { isolates }\end{array}$ & $\begin{array}{c}\text { sumber of } \\
\text { plasmids }\end{array}$ & pLR7 & pLR20 \\
\cline { 3 - 4 } & 34 & $22(65)$ & $5(15)$ \\
UK AIDS patients & 12 & $8(67)$ & $3(25)$ \\
USA AIDS patients & 12 & $6(50)$ & $2(17)$ \\
UK non-AIDS patients & 2 & $1(50)$ & $0(0)$ \\
Veterinary & 60 & $37(62)$ & $10(17)$ \\
$\quad$ Total & & & \\
\hline
\end{tabular}

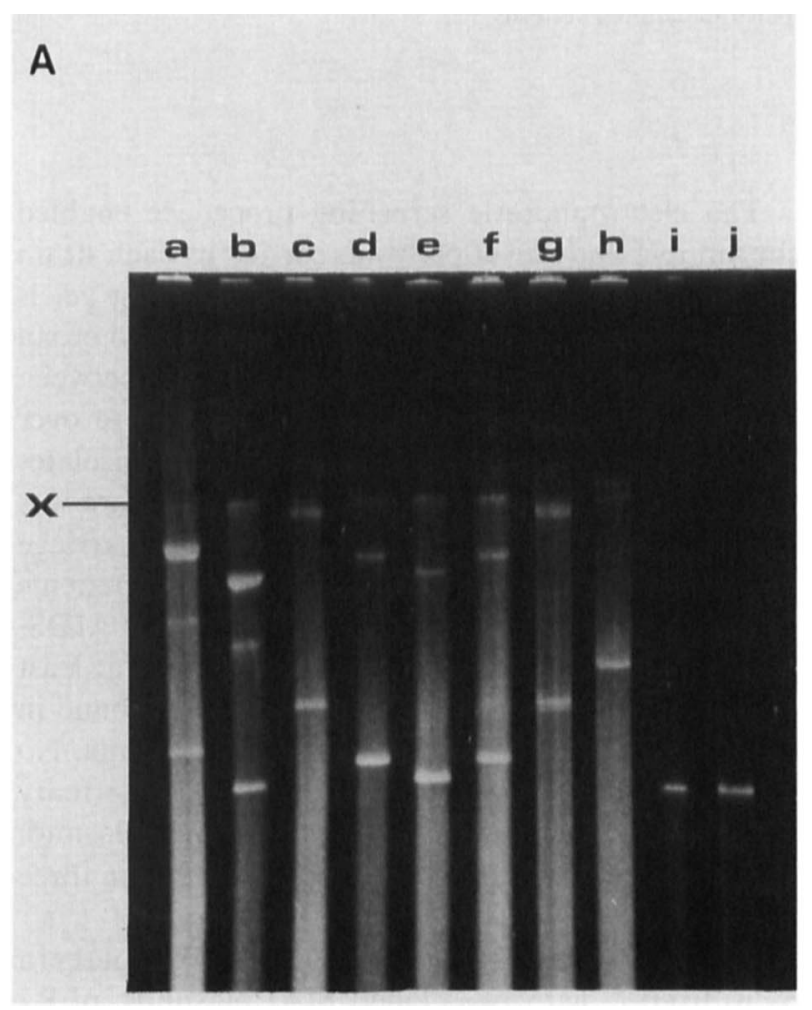

common. The probes did not hybridise to either the large plasmids or chromosomal DNA. No small plasmids were found with homology to both probes.

Southern blot analysis of intact plasmids is a relatively crude method of determining the relationship between plasmids from different strains because hybridisation may be due to only small regions of homology. For this reason, we analysed restriction endonuclease digests of plasmid DNA by agarose-gel electrophoresis and Southern hybridisation. As has been reported previously, ${ }^{11}$ there was considerable variation in size (15-30 kb) of pLR7-related plasmids (fig. 2a), and in the hybridisation patterns of digested

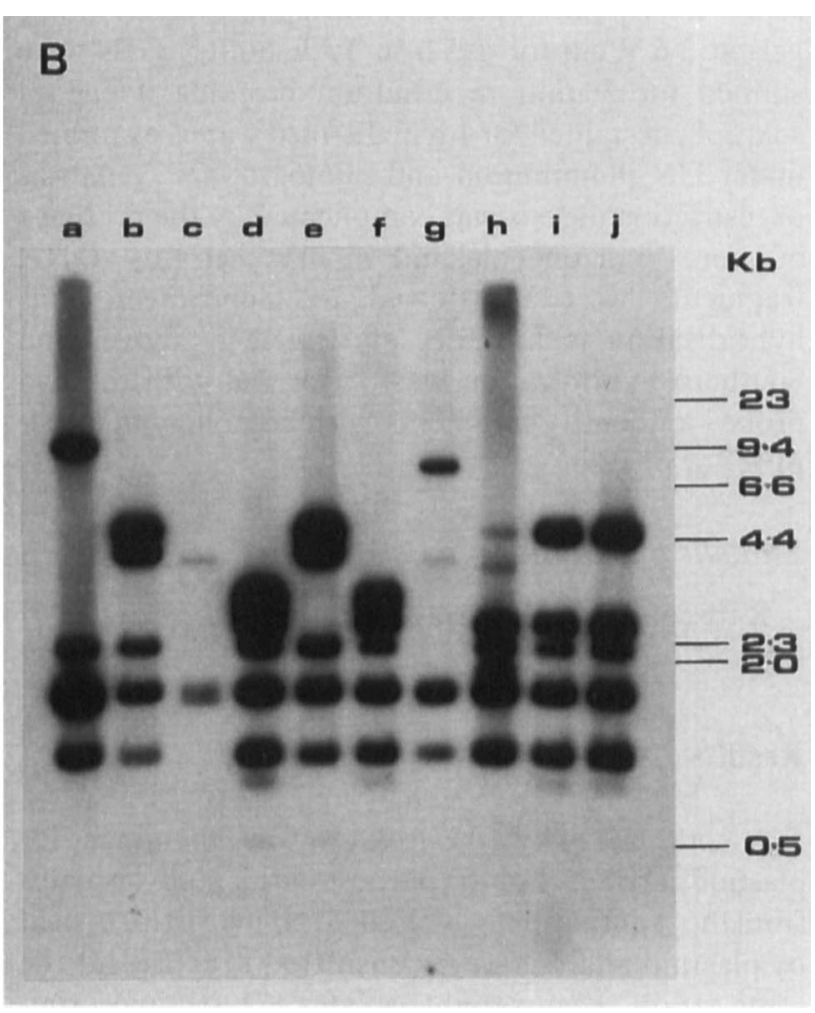

Fig. 2. Diversity in size and BstEII restriction patterns of pLR7-related plasmids. A. Plasmid DNA prepared with the Qiagen DNA purification system and subjected to electrophoresis in agarose $0.5 \%$, TAE buffer at $1.8 \mathrm{~V} / \mathrm{cm}$ for $16 \mathrm{~h}$. Migration was from top to bottom. The fastest running bands correspond to supercoiled plasmid DNA. The position of the chromosomal DNA band is marked (X). Remaining bands correspond to partially denatured plasmid DNA. Strain sources: a, veterinary; b, unknown; c, d, UK non-AIDS patients; e-i, UK AIDS patients; j, strain LR113 (carrying the 15·3-kb pLR7 plasmid ${ }^{19}$ ). B. Autoradiograph of BstEII digests of plasmid DNA hybridised with recombinant pLR7. Strains are in the same lanes as in A. Linear size markers indicated are the HindIII fragments of phage $\lambda$. 
Table III. Plasmid carriage, hybrisation patterns and isolation site of MAI isolates from different sources

\begin{tabular}{|c|c|c|c|c|c|}
\hline \multirow[b]{3}{*}{ Origin of isolate } & \multirow{3}{*}{$\begin{array}{l}\text { Number of } \\
\text { isolates* }\end{array}$} & \multicolumn{4}{|c|}{ Number (\%) of isolates carrying } \\
\hline & & \multirow[b]{2}{*}{ plasmids } & \multicolumn{2}{|c|}{ plasmids hybridising with } & \multirow{2}{*}{$\begin{array}{c}\text { large } \\
\text { plasmids }\end{array}$} \\
\hline & & & pLR7 & pLR20 & \\
\hline \multicolumn{6}{|l|}{$U K$ AIDS patients } \\
\hline Alimentary tract & 28 & $13(46)$ & $7(25)$ & $2(7)$ & $7(25)$ \\
\hline Respiratory & 25 & $12(48)$ & $7(28)$ & $2(8)$ & $7(28)$ \\
\hline Blood/bone marrow & 17 & $8(47) \dagger$ & $5(29)$ & $0(0)$ & $4(24)$ \\
\hline Other/unknown & 9 & $6(67)$ & $6(67)$ & $1(11)$ & $2(22)$ \\
\hline \multicolumn{6}{|l|}{ USA AIDS patients } \\
\hline Blood & 9 & $9(100) \dagger$ & $8(89)$ & $3(33)$ & $8(89)$ \\
\hline \multicolumn{6}{|l|}{ UK non-AIDS patients } \\
\hline Respiratory & 16 & $6(38)$ & $3(19)$ & $1(6)$ & $3(19)$ \\
\hline Other/unknown & 18 & $6(33)$ & $3(17)$ & $1(6)$ & $3(17)$ \\
\hline
\end{tabular}

fragments (fig. 2b). In contrast, plasmids with homology to pLR20 were more consistent in size (c. 14 $16 \mathrm{~kb}$ ) and BstEII-digest banding patterns (data not shown). There was some variation in the size of the large plasmids, although this could not be quantified accurately.

Plasmids with homology to pLR20 were always found in the presence of another small plasmid and were always the smallest plasmid present. Eight of 10 strains which possessed a plasmid related to pLR20 also carried a plasmid related to pLR7. Thirteen small plasmids were isolated (seven from AIDS-related and four from non-AIDS MAI strains isolated in the UK, one plasmid from an American AIDS MAI strain, and one MAI strain of veterinary origin) which were unrelated to either pLR7 or pLR20 by Southern blot analysis. These plasmids have yet to be characterised.

In patients with AIDS, similar rates of plasmid carriage were observed in MAI isolates from different parts of the body (table III). There was no significant

Table IV. Plasmid carriage and serotype of AIDS-related MAI strains isolated in the UK

\begin{tabular}{cccc}
\hline & & \multicolumn{2}{c}{ Number of strains carrying } \\
\cline { 3 - 4 } Serotype & $\begin{array}{c}\text { Number } \\
\text { of strains }\end{array}$ & plasmids & $\begin{array}{c}\text { plasmids hybridising } \\
\text { with pLR7 }\end{array}$ \\
\hline 1 & 4 & 2 & 2 \\
4 & $15^{*}$ & 8 & 8 \\
8 & 6 & 6 & 6 \\
9 & 4 & 3 & 1 \\
Not typable & 4 & 2 & 0 \\
Other & 13 & 4 & 1 \\
Total & 46 & 25 & 18 \\
\hline
\end{tabular}

* Includes two strains of mixed serotype; one of which carried a plasmid that hybridised to pLR7. difference in the rate of plasmid carriage between MAI isolates from the respiratory tract in AIDS and non-AIDS patients. All the American AIDS-associated strains were isolated from blood and carried plasmids. In contrast, only $8(47 \%)$ of 17 strains isolated from the blood or bone marrow of AIDS patients in the UK possessed plasmid DNA $(p<0 \cdot 01)$.

It is possible that plasmid carriage and serotype are linked in the pathogenesis of MAI in AIDS. In this study (table IV), 14 (67\%) of 21 serotype 4 or serotype 8 MAI isolates from UK AIDS patients carried plasmid DNA (in all cases including a pLR7-related plasmid). Amongst all other serotypes, 11 (44\%) of 25 strains carried a plasmid, but only four of these strains possessed a plasmid which hybridised to pLR7. The difference in the carriage of pLR7-related plasmids between strains of serotype 4 or serotype 8 and strains of other serotypes was highly significant $(p<0.005)$.

\section{Discussion}

Our interest in MAI plasmids was prompted by the fact that they may help to explain the specific association between MAI colonisation and infection in late-stage HIV (human immunodeficiency virus) disease. MAI has been found in $17-28 \%$ of AIDS patients before death ${ }^{23,24}$ and in over $50 \%$ of patients examined post mortem $;{ }^{1-3}$ yet this group of organisms is no more common in the environment than many other atypical mycobacteria. There is increasing evidence that the portal of entry may be the gastrointestinal tract. ${ }^{1-6}$ Work in progress at St Mary's Hospital suggests that individuals without HIV infection do not carry MAI in their faeces, and that MAI appears in the faeces at a late stage in the progression of HIV infection (unpublished observation). 
Analysis of AIDS-associated MAI strains suggests that they belong to a special sub-group of organisms defined by DNA fingerprinting, ${ }^{25}$ serological type ${ }^{7,26}$ and plasmid carriage. ${ }^{11}$ The hypothesis we wish to test is that plasmids play a role in the establishment of MAI in AIDS patients.

Crawford and Bates ${ }^{11}$ showed that all AIDSassociated MAI strains from a group of American patients carried plasmids. In contrast, in this study only $48 \%$ of AIDS-associated MAI isolates carried plasmids. This level was not significantly higher than the $35 \%$ plasmid carriage rate found in MAI isolates from clinical sources not associated with AIDS or HIV infection. All the AIDS-associated MAI strains of American origin that we examined possessed plasmids, but the sample of nine is too small to say whether this finding reinforces that of Crawford et al., and that there is a real difference between AIDSassociated MAI strains from America and from the UK. The rate of plasmid carriage observed amongst clinical isolates of MAI not associated with AIDS was similar to that reported from Denmark by Jensen et al., ${ }^{27}$ but lower than the figures of $52 \%$ and $56 \%$ reported from Japan and the USA. ${ }^{28,} 29$

The American strains we screened for plasmid carriage were all isolated from blood, but plasmid carriage could not be correlated with the site of isolation in strains from the UK. However, there was a strong association between plasmid carriage and serotypes 4 and 8 among the UK MAI strains. All the American strains analysed by Crawford and Bates ${ }^{11}$ were serotype 4 or serotype 8 . Unfortunately, the serotypes of our panel of American AIDS strains were not known. It would be interesting to determine whether American AIDS-associated MAI strains that were not of serotype 4 or serotype 8 had a lower rate of plasmid carriage. There is also a need to examine more environmental and veterinary strains.

We have used Southern hybridisation analysis to define two distinct groups of small plasmids in MAI strains. The most frequently isolated plasmids were those with homology to pLR7. Plasmids from this group were significantly more common in the serotypes most often associated with AIDS. However, carriage of a pLR7-related plasmid was not restricted to strains of these serotypes and possession of a large or small plasmid was not a pre-requisite for the ability to cause disease in patients with or without AIDS.

It is evident from the diversity in size and restrictionfragment patterns of pLR7-related plasmids that many carry only relatively short sequences with homology to pLR7. Therefore, these plasmids may encode a variety of different functions. There may be some coordination of function between different plasmids because pLR20-related plasmids were found only in the presence of another small plasmid. There is still little information concerning the degree of relatedness amongst large plasmids isolated from different strains. This is primarily a result of their size and the difficulty in obtaining sufficient DNA with which to work. The large plasmids are present within the cell in low copy number and are easily damaged by the harsh conditions required to disrupt the mycobacterial cell wall and for the subsequent purification procedures. These problems may be overcome by cloning fragments of the large plasmids into suitable bacteriophage or cosmid vectors.

The existence of plasmids in MAI has been implicated in several characteristics; $;^{16,28,30,31}$ of particular interest are the recent studies in which plasmids have been associated with the virulence of MAI. ${ }^{12-14}$ An important factor in the present context may be the ability to penetrate the gastrointestinal epithelium and survive within the gut-associated lymphoid tissues; mycobacterial cell-wall adhesins that react with receptors on the mucosal surface may be involved in this process. ${ }^{32-34}$ Plasmids are known to encode such properties in other organisms, ${ }^{35-37}$ and the importance of MAI plasmids in relation to these processes warrants further investigation.

The ability to distinguish MAI isolates from patients with and without AIDS by serological and genetic analysis $^{7,10,25,26}$ may simply reflect the characteristics of those strains present in the environment, but such observations may also serve as markers for differences in the pathology of MAI infection between these patient groups. We have established that plasmid profiles are useful epidemiological markers for the identification of repeat isolates of the same strain of MAI. In conjunction with serological typing and DNA fingerprinting, plasmid characterisation of clinical and environmental strains of MAI should enable potential sources of infection to be identified and establish the likely route of infection in patients with AIDS. Data from these typing systems would provide valuable insight into the importance of plasmid DNA in the ability of MAI to cause AIDS-associated disease.

Most studies on the functions of plasmids in MAI have been based on comparisons between ill-defined plasmid-free segregants produced by chemical mutagenesis. ${ }^{12,13,16,30}$ However the recent development of suitable systems for the transfer and expression of foreign genes in mycobacteria ${ }^{38-41}$ should help elucidate the roles played by plasmid DNA in the pathogenesis of this increasingly important group of organisms.

We are indebted to our colleagues in the Departments of Medicine, Immunology and Venereology at St Mary's Hospital for their co-operation during this study. The project was supported by the Medical Research Council. 


\section{References}

1. Armstrong D, Gold JWM, Dryjanski J et al. Treatment of infections in patients with the acquired immunodeficiency syndrome. Ann Intern Med 1985; 103: 738-743.

2. Kiehn TE, Edwards FF, Brannon $P$ et al. Infections caused by Mycobacterium avium complex in immunocompromised patients : diagnosis by blood culture and fecal examination, antimicrobial susceptibility tests, and morphological and seroagglutination characteristics. J Clin Microbiol 1985; 21: $168-173$

3. Hawkins CC, Gold JWM, Whimbey E et al. Mycobacterium avium complex infections in patients with the acquired immunodeficiency syndrome. Ann Intern Med 1986; 105: 184-188.

4. Damsker B, Bottone EJ. Mycobacterium avium-Mycobacterium intracellulare from the intestinal tracts of patients with the Acquired Immunodeficiency Syndrome: concepts regarding acquisition and pathogenesis. $J$ Infect Dis $1985 ; 151$ : 179-181.

5. Kiehn TE, Cammarata R. Laboratory diagnosis of mycobacterial infections in patients with Acquired Immunodeficiency Syndrome. J Clin Microbiol 1986; 24: 708-711.

6. Stacey AR. Isolation of Mycobacterium avium-intracellularescrofulaceum complex from faeces of patients with AIDS. BrMed J 1986; 293: 1194

7. Good RC. Opportunistic pathogens in the genus Mycobacterium. Annu Rev Microbiol 1985; 39 : 347-369.

8. Baess I. Deoxyribonucleic acid relatedness among species of slowly-growing mycobacteria. Acta Path Microbiol Scand [B] 1979; 87: 221-226.

9. Baess I. Deoxyribonucleic acid relationships between different serovars of Mycobacterium avium, Mycobacterium intracellulare and Mycobacterium scrofulaceum. Acta Path Microbiol Immunol Scand [B] 1983; 91 : 201-203.

10. Guthertz LS, Damsker B, Bottone EJ, Ford EG, Midura TF, Janda JM. Mycobacterium avium and Mycobacterium intracellulare infections in patients with and without AIDS. $J$ Infect Dis 1989; 160: 1037-1041.

11. Crawford JT, Bates JH. Analysis of plasmids in Mycobacterium avium-intracellulare isolates from persons with Acquired Immunodeficiency Syndrome. Am Rev Respir Dis 1986 134: 659-661.

12. Pethel ML, Falkinham JO. Plasmid-influenced changes in Mycobacterium avium catalase activity. Infect Immun 1989; 57: 1714-1718.

13. Gangadharam PRJ, Perumal VK, Crawford JT, Bates JH Association of plasmids and virulence of Mycobacterium avium complex. Am Rev Respir Dis 1988; 137: 212-214.

14. Gangadharam PRJ, Perumal VK, Jairam BT, Podapati NR, Taylor RB, LaBrecque JF. Virulence of Mycobacterium avium complex strains from acquired immunodeficiency syndrome patients; relationship with characteristics of the parasite and host. Microb Pathog 1989; 7: 263-278.

15. Schaefer WB. Serologic identification and classification of the atypical mycobacteria by their agglutination. $A m R e v$ Respir Dis 1965; 92: 85-93.

16. Crawford JT, Cave MD, Bates JH. Evidence for plasmidmediated restriction modification in Mycobacterium aviumintracellulare. J Gen Microbiol 1981 ; 127 : 333-338.

17. Kieser T. Factors affecting the isolation of ccc DNA from Streptomyces lividans and Escherichia coli. Plasmid 1984; 12: 19-36.

18. Crawford JT, Cave MD, Bates JH. Characterization of plasmids from strains of Mycobacterium avium-intracellulare. Rev Infect Dis 1981; 3: 949-952.

19. Crawford JT, Bates JH. Restriction endonuclease mapping and cloning of Mycobacterium intracellulare plasmid pLR7. Gene 1984; 27 : 331-333.

20. Vieira J, Messing J. The pUC plasmids, an M13mp7-derived system for insertion mutagenesis and sequencing with synthetic universal primers. Gene 1982; 19: 259-268.

21. Feinberg AP, Vogelstein B. A technique for radiolabeling DNA restriction endonuclease fragments to high specific activity. Anal Biochem 1983; 132: 6-13.

22. Feinberg AP, Vogelstein B. Addendum: a technique for the radiolabeling of DNA restriction endonuclease fragments to high specific activity. Anal Biochem 1984; 137: 266-267.

23. Fauci AS, Macher AM, Longo DL et al. Acquired Immunodeficiency Syndrome: epidemiologic, clinical, immunologic, and therapeutic considerations. Ann Intern Med 1984; 100: 92-106.

24. Murray JF, Felton CP, Garay SM et al. Pulmonary complications of the Acquired Immunodeficiency Syndrome. $N$ Engl $J$ Med 1984; 310: 1682-1688.

25. Hampson SJ, Portaels F, Thompson J et al. DNA probes demonstrate a single highly conserved strain of Mycobacterium avium infecting AIDS patients. Lancet 1989; 1 : 6568.

26. Horsburgh CR, Cohn DL, Roberts RB et al. Mycobacterium avium- $M$. intracellulare isolates from patients with or without Acquired Immunodeficiency Syndrome. Antimicrob Agents Chemother 1986; 30: 955-957.

27. Jensen AG, Bennedsen J, Rosdahl VT. Plasmid profiles of Mycobacterium avium-intracellulare isolated from patients with AIDS or cervical lymphadenitis and from environmental samples. Scand J Infect Dis 1989; 21 : 645-649.

28. Franzblau SG, Takeda T, Nakamura M. Mycobacterial plasmids: screening and possible relationship to antibiotic resistance in Mycobacterium avium/Mycobacterium intracellulare. Microbiol Immunol 1986; 30: 903-907.

29. Meissner PS, Falkinham JO. Plasmid DNA profiles as epidemiological markers for clinical and environmental isolates of Mycobacterium avium, Mycobacterium intracellulare, and Mycobacterium scrofulaceum. J Infect Dis 1986; 153: $325-331$

30. Mizuguchi $Y$, Fukunaga M, Taniguchi $H$. Plasmid deoxyribonucleic acid and translucent-to-opaque variation in $\mathrm{Myco-}$ bacterium intracellulare 103. J Bacteriol 1981; 146: 656-659.

31. Fry KL, Meissner PS, Falkinham JO. Epidemiology of infection by nontuberculous mycobacteria: VI. Identification and use of epidemiologic markers for studies of Mycobacterium avium, M. intracellulare, and $M$. scrofulaceum. Am Rev Respir Dis 1986; 134: 39-43.

32. Mapother ME, Songer JG. In vitro interaction of Mycobacterium avium with intestinal epithelial cells. Infect Immun 1984; 45: $67-73$

33. Thorel M-F, David HL. Specific surface antigens of SmT variants of Mycobacterium avium. Infect Immun 1984; 43: 438-439.

34. Williams RC, Husby G, Koster FT. Well-defined cell-surface receptors may be entry points for infectious agents. Scand J Immunol 1986; 23: 529-533.

35. Maurelli AT, Baudry B, d'Hauteville H, Hale TL, Sansonetti PJ. Cloning of plasmid DNA sequences involved in invasion of HeLa cells by Shigella flexneri. Infect Immun $1985 ; 49: 164-171$

36. Sansonetti PJ, d'Hauteville $H$, Ecobichon C, Pourcel C. Molecular comparison of virulence plasmids in Shigella and enteroinvasive Escherichia coli. Ann Microbiol (Paris) 1983; 134A: 295-318.

37. Jones GW, Rabert DK, Svinarich DM, Whitfield HJ. Association of adhesive, invasive, and virulent phenotypes of Salmonella typhimurium with autonomous 60-megadalton plasmids. Infect Immun 1982; 38: 476-486.

38. Jacobs WR, Tuckman M, Bloom BR. Introduction of foreign DNA into mycobacteria using a shuttle plasmid. Nature $1987 ; 327: 532-535$.

39. Snapper SB, Lugosi L, Jekkel A et al. Lysogeny and transformation in mycobacteria : stable expression of foreign genes. Proc Natl Acad Sci USA 1988; 85: 6987-6991.

40. Lugosi L, Jacobs WR, Bloom BR. Genetic transformation of BCG. Tubercle 1989; 70: 159-170.

41. Zainuddin ZF, Kunze ZM, Dale JW. Transformation of Mycobacterium smegmatis with Escherichia coli plasmids carrying a selectable resistance marker. Mol Microbiol $1989 ; 3: 29-34$ 
